\title{
Mature Gastric Teratoma
}

National Cancer Institute

\section{Source}

National Cancer Institute. Mature Gastric Teratoma. NCI Thesaurus. Code C5260.

A benign teratoma that arises from the stomach. It contains mature tissue elements

only. 